The Long Shadow 



\section{The Long Shadow}

NUCLEAR WEAPONS AND SECURITY

I N 2 IST CENTURY ASIA

Edited by

Muthiah Alagappa

STANFORD UNIVERSITY PRESS

Stanford, California 2008 
Stanford University Press

Stanford, California

(C) 2008 by the Board of Trustees of the Leland Stanford Junior

University. All rights reserved.

No part of this book may be reproduced or transmitted in any form or by any means, electronic or mechanical, including photocopying and recording, or in any information storage or retrieval system without the prior written permission of Stanford University Press.

Printed in the United States of America on acid-free, archival-quality paper

Library of Congress Cataloging-in-Publication Data

The long shadow : nuclear weapons and security in 2 Ist century Asia / edited by Muthiah Alagappa.

p. $\mathrm{cm}$.

Includes bibliographical references and index.

ISBN 978-0-8047-6086-7 (cloth : alk. paper)-

ISBN 978-0-8047-6087-4 (pbk. : alk. paper)

I. Nuclear weapons-Government policy-Asia. 2. National

security-Asia. 3. Security, International-Asia. 4. Asia-

Military policy—2Ist century. I. Alagappa, Muthiah.

UA830.L66 2008

355.02 'I $7095-\mathrm{dc} 22$

Typeset by Thompson Type in Io/ı3 Bembo 